\title{
Pengaruh Cekaman Nitrogen dan Fotoperiode terhadap Kurva pertumbuhan Kultur Nannochloropsis sp.
}

\author{
S. Dwirejeki dan D. Ermavitalini \\ Departemen Biologi, Fakultas Sains, Institut Teknologi Sepuluh Nopember (ITS) \\ e-mail:dinierma@bio.its.ac.id
}

\begin{abstract}
Abstrak-Konsumsi energi meningkat dari tahun ke tahun dan 95\% terpenuhi dari bahan fosil yang jumlahnya terbatas. Biodiesel sebagai alternatif sumber energi dari tanaman jarak (Jatropha curcas) dan kelapa sawit memiliki kemampuan oksidasi yang rendah pada suhu dingin, produksi lipid membutuhkan waktu lama serta kandungan lipid yang berkisar $35 \%$ dan $75,6 \%$. Di sisi lain, Nannochloropsis sp. dapat memproduksi lipid mencapai $90 \%$ dari berat kering biomassa pada kondisi tercekam, panen lebih cepat, mudah dibudidayakan. Waktu panen kultur Nannochloropsis sp. dapat direkayasa berdasarkan nutrisi, suhu, aerasi, salinitas, fotoperiode. Penelitian ini bertujuan untuk menguji pengaruh cekaman nitrogen dan fotoperiode terhadap lama waktu panen kultur. Nannochloropsis sp., dikultur pada kondisi normal untuk mendapatkan masa starter (setengah eksponensial kultur). Kultur Nannochloropsis sp. pada masa starter diberikan perlakuan kombinasi nitrogen pada pupuk Conway terdiri dari $0 \%, 25 \%, 50 \%, 75 \%$ dan $100 \% \mathrm{NaNO}_{3}$ dengan fotoperiode (terang:gelap) 12:12, 16:8 dan 24:0. Kultur Nannochloropsis sp. dengan nitrogen terbatas memiliki fase eksponensial yang lebih singkat sedangkan pada perlakuan fotoperiode dengan terang lebih lama, kultur memiliki nilai OD yang paling tinggi. Waktu panen paling cepat yaitu perlakuan dengan nitrogen $0 \%$, nilai OD paling tinggi pada pemberian nitrogen $100 \%$ pada berbagai fotoperiode.
\end{abstract}

Kata Kunci-Eksponensial, Fotoperiode, Nannochloropsis sp., Nitrogen, Starter.

\section{PENDAHULUAN}

$\mathbf{I}_{k}^{\mathrm{N}}$ NDONESIA merupakan negara kepulauan yang memiliki kekayaan alam yang melimpah namun ketersediaan energi dari tahun ke tahun mengalami penurunan/krisis. Krisis energi tersebut terjadi karena tingginya konsumsi energi oleh penduduk meliputi sektor industri $(50 \%)$, transportasi (34\%), rumah tangga (12\%) dan komersial (4\%). Konsumsi energi Indonesia yang cukup tinggi tersebut hampir $95 \%$ dipenuhi dari bahan bakar fosil. Dari total tersebut, hampir 50\% merupakan Bahan Bakar Minyak (BBM). Sebagai sumber energi tidak terbarukan, cadangan BBM Indonesia sangat terbatas [1] sehingga diperlukan sumber energi alternatif untuk menggantikan fungsi BBM, salah satunya memanfaatkan sumber daya hayati baik dari lemak hewani maupun nabati [1] sebagai biodiesel. Namun, sumber lemak nabati (lemak dari tanaman jarak (Jatropha curcas), kelapa sawit/palm) dan lemak hewani masih memiliki kekurangan untuk dijadikan sebagai biodiesel karena memiliki kemampuan oksidasi yang rendah pada suhu dingin [2] laju pertumbuhan rendah sehingga produksi lipid memerlukan waktu yang lama [3]. Untuk mengatasi kekurangan tersebut dapat memanfaatkan mikroalga atau fitoplankton [4] sebagai alternatif biodiesel.
Mikroalga laut, Nannochloropsis sp. memiliki kandungan lemak yang cukup tinggi yakni sebesar 12,0$53,0 \%$ berat kering biomassa tetapi jika di bawah kondisi tercekam kandungan lemak mencapai $90 \%$ dari berat keringnya [4][5] yang lebih tinggi daripada lipid jarak pagar sebesar 35\% berat kering [6] dan kelapa sawit sebesar $75,6 \%$ [7]. Nannochloropsis sp juga memiliki laju pertumbuhan yang tinggi [3], memiliki kinerja lebih baik pada cuaca dingin karena mengandung PUFA dengan titik cair yang lebih rendah jika dibandingkan dengan asam lemak jenuh [2]. Kandungan lipid serta keunggulan Nannochloropsis tersebut berpotensi sebagai alternatif bahan biodiesel melalui proses kimia transesterifikasi [8].

Produksi lipid dan waktu panen Nannochloropsis dapat direkayasa berdasarkan kondisi kultur, seperti mengubah konsentrasi nutrisi dari media, pengaturan suhu, aerasi $\mathrm{CO}_{2}$, salinitas, intensitas cahaya dan fotoperiode [8] karena pada kondisi yang tidak menguntungkan mikroalga mengubah jalur biosintesis lipid menuju pembentukan dan akumulasi lipid netral dalam bentuk triasilgliserol sebagai pertahanan [9]. Kondisi cekaman lingkungan tersebut juga dapat menurunkan kecepatan pembelahan sel, sel akan merangkai asam lemak menjadi lipid simpanan berupa triasilgliserol untuk mengisi ketersediaan $\mathrm{NADP}^{+}$karena saat nutrisi atau lingkungan tercekam, $\mathrm{NADP}^{+}$mengalami penurunan sehigga NADPH yang dihasilkan dari fotosintesis dikonsumsi untuk pembentukan asam lemak [10]. Perlakuan cekaman nitrogen dapat meningkatkan produksi lipid yang lebih tinggi [11][12] karena protein dari mikroalga terpecah menjadi Asetil-KoA. Cekaman fotoperiode dapat meningkatkan panen lipid mikroalga serta mempengaruhi fotosinteis untuk produksi biomassa, kondisi terang dibutuhkan dalam fase fotokimia pembentukan ATP dan NADPH sedangkan kondisi gelap mempengaruhi sintesis biokimia molekul untuk pertumbuhan meliputi pembentukan protein, karohidrat dan lemak [8]. Dalam penelitian ini akan dilakukan uji pengaruh kombinasi perlakuan pemberian berbagai konsentrasi nitrogen dan fotoperiode terhadap waktu panen Nannochloropsis sp.

\section{URAIAN PENELITIAN}

\section{A. Persiapan Alat dan Bahan}

Peralatan yang digunakan dalam penelitian ini adalah neraca analitik, spektrofotometer Uv-Vis, autoklaf, oven, $\mathrm{pH}$-meter, lux-meter, hand refraktometer. Bahan yang digunakan dalam penelitian ini meliputi air laut, vitamin B, unsur maro dan mikro pupuk Conway, kultur murni Nannochloropsis sp., alkohol 96\%, aquades, aquabides, kertas tisu. 


\section{B. Persiapan Sampel dan Media Kultur}

Sampel yang digunakan adalah mikroalga jenis Nannochloropsis sp. yang diperoleh dari stok murni Laboratorium Pakan Alami Balai Perikanan dan Budidaya Air Payau (BBPAP) Situbondo dengan kepadatan stok awal $10^{6} \mathrm{sel} / \mathrm{ml}$. Selanjutnya dilakukan kultur untuk penentuan masa starter dan masa panen dengan presentase $10 \%$ mikroalga dalam air laut steril. Air laut diperoleh dari penyedia komersil. Media yang digunakan untuk kultur mikroalga Nannochloropsis sp. adalah air laut [13]. Air laut disaring dengan membran filter, kemudian diukur salinitas pada 30-32 ppt [14][15] pH 7-8, intensitas cahaya terang 900-1000 lux, gelap 0-10 lux, suhu 25-27 ${ }^{\circ} \mathrm{C}$ [15].

\section{Pembuatan Pupuk Conway}

Pupuk yang digunakan dalam penelitian ini adalah pupuk Conway yang terdiri dari 5 jenis konsentrasi $\mathrm{NaNO}_{3}$ sebagai variasi perlakuan cekaman nutrisi nitrogen [16] yang terdiri dari $100 \%, 75 \%, 50 \%, 25 \%$ dan 0\%. Komposisi $100 \%$ pupuk Conway terdiri 100 gram $\mathrm{NaNO}_{3}$ dilarutkan dalam 1 $\mathrm{L}$ aquades [12]. Tabel 1 adalah komposisi pupuk Conway dalam $1 \mathrm{~L}$ aquades steril [12]:

\section{Tabel 1.} Komposisi Pupuk Conway

\begin{tabular}{|c|c|}
\hline Komposisi & Konsentrasi \\
\hline $\mathrm{Na}_{2}$ EDTA & $45 \mathrm{~g} / \mathrm{L}$ \\
\hline $\mathrm{FeCl}_{2} \cdot 6 \mathrm{H}_{2} \mathrm{O}$ & $1,3 \mathrm{~g} / \mathrm{L}$ \\
\hline $\mathrm{H}_{3} \mathrm{BO}_{7}$ & $33,6 \mathrm{~g} / \mathrm{L}$ \\
\hline $\mathrm{NaH}_{2} \mathrm{PO}_{4}$ & $20 \mathrm{~g} / \mathrm{L}$ \\
\hline $\mathrm{MnCl}_{2} \cdot 4 \mathrm{H}_{2} \mathrm{O}$ & $0,36 \mathrm{~g} / \mathrm{L}$ \\
\hline $\mathrm{NaNO}_{3}$ & $100 \mathrm{~g} / \mathrm{L}$ \\
\hline Trace metal solution & $1 \mathrm{ml}$ \\
\hline 1. $\mathrm{ZnCl} 2$ & $2,1 \mathrm{~g} / \mathrm{L}$ \\
\hline 2. $\mathrm{CoCl} 2.6 \mathrm{H} 2 \mathrm{O}$ & $2 \mathrm{~g} / \mathrm{L}$ \\
\hline 3. (NH4) $6 \mathrm{Mo} 7 \mathrm{O} 24.4 \mathrm{H} 2 \mathrm{O}$ & $0,9 \mathrm{~g} / \mathrm{L}$ \\
\hline 4. $\mathrm{CuSO} 4.5 \mathrm{H} 2 \mathrm{O}$ & $2 \mathrm{~g} / \mathrm{L}$ \\
\hline 5. Aquades (Sousa et al, 2014) & $1 \mathrm{~L}$ \\
\hline Vitamin & $1 \mathrm{ml}$ \\
\hline 1. Vitamin B12 & $10 \mathrm{mg}$ \\
\hline 2. Vitamin B1 & $200 \mathrm{mg}$ \\
\hline 3. Aquabides & $200 \mathrm{ml}$ \\
\hline
\end{tabular}

Media kultur pada penelitian ini menggunakan pupuk Conway dengan konsentrasi $1 \mathrm{ml}$ per 1 L komposisi kultur.

\section{Sterilisasi Alat dan Bahan}

Pupuk yang digunakan dalam penelitian ini adalah pupuk Conway yang terdiri dari 5 jenis konsentrasi $\mathrm{NaNO}_{3}$ sebagai variasi perlakuan cekaman nutrisi nitrogen (Yarti dkk, 2014), yang terdiri dari $100 \%, 75 \%, 50 \%, 25 \%$ dan $0 \%$. Komposisi $100 \%$ pupuk Conway terdiri 100 gram $\mathrm{NaNO}_{3}$ dilarutkan dalam $1 \mathrm{~L}$ aquades [12]. Berikut adalah komposisi pupuk Conway dalam $1 \mathrm{~L}$ aquades steril [12]: Sterilisasi alat yang dilakukan meliputi sterilisasi botol kultur, pipet tetes, pipet volume, gelas ukur, erlenmeyer. Sterilisasi alat tersebut dilakukan dengan perendaman chlorin selama 24 jam dan dicuci dengan pembersih/detergen kemudian dibilas dengan air mengalir, dikeringkan, kemudian dibungkus dengan plastik tahan panas dan disterilisasi dengan autoklaf pada suhu $121{ }^{\circ} \mathrm{C}$ selama 15 menit pada tekanan 15 pt [17].

Sterilisasi bahan meliputi tisu, karet, air laut, aquadest, aquabidest. Air laut, aquabidest, aquadest dimasukkan ke dalam botol kultur sedangkan tisu dan karet dibungkus dengan plastic tahan panas, kemudian disterilisasi dengan autoclave pada suhu $121{ }^{\circ} \mathrm{C}$ selama 15 menit pada tekanan 15 pt [17].

\section{E. Penentuan Starter Kultur Nannocgloropsis sp.}

Penentuan waktu panen dilakukan dengan membuat kultur $10 \%$ mikroalga dalam $200 \mathrm{ml}$ kultur. Kultur Nannochloropsis sp. diukur setiap 24 jam hingga mencapai fase kematian dengan menggunakan spektrofotoneter UVVis pada panjang gelombang $680 \mathrm{~nm}$ [18] sehingga membentuk kurva pertumbuhan dengan koordinat dimana $\mathrm{x}$ adalah hari kultur dan y adalah nilai OD. Masa starter merupakan masa setengah eksponensial dari kultur Nannochloropsis sp. [18][19].

\section{F. Penentuan Waktu Panen Nannocgloropsis sp.}

Penentuan waktu panen dilakukan dengan membuat kurva pertumbuhan Nannochlorpsis sp. pada kultur mikroalga yang diberikan perlakuan cekaman. Perlakuan Fotoperiode dilakukan dengan memberikan cahaya pada kultur dengan terang:gelap meliputi 24:0 (kontinyu), 16:8, 12:12. Perlakuan cekaman nitrogen terbagi menjadi 5 variasi yaitu pemberian pupuk Conway $100 \%$ NaNO3, $75 \%$ NaNO3, $50 \%$ NaNO3, 25\% NaNO3 dan 0\% NaNO3. Kombinasi perlakuan kultur berjumlah 15 diukur setiap 24 jam hingga mencapai fase kematian dengan menggunakan spektrofotoneter UVVis pada panjang gelombang $680 \mathrm{~nm}$ [18][19]sehingga membentuk kurva pertumbuhan dengan koordinat dimana $\mathrm{x}$ adalah hari kultur dan y adalah nilai OD. Fase akhir eksponensial ditetapkan sebagai waktu panen kultur Nannochloropsis sp. [20][21], dan [22].

\section{G. Perlakuan}

Perlakuan dilakukan dengan memasukkan $50 \mathrm{ml}$ mikroalga dalam $450 \mathrm{ml}$ air laut steril dan pupuk Conway $0,5 \mathrm{ml}$ [13][17] hingga masa starter dengan salinitas $30 \mathrm{ppt}$, pH 7-8 [12], intensitas cahaya terang 900-1000 lux, gelap 010 lux, suhu $25-27{ }^{\circ} \mathrm{C}$ [23]. Kultur dari masa starter diambil $50 \mathrm{ml}$ untuk dikultur kembali dalam $450 \mathrm{ml}$ air laut steril dengan kondisi tercekam fotoperiode dan nitrogen hingga masa panen. Tabel 2 merupakan kombinasi perlakuan pada penelitian ini:

Tabel 2.

Kombinasi Perlakuan

\begin{tabular}{cccc}
\multicolumn{4}{c}{ Kombinasi Perlakuan } \\
\hline \hline Variasi Nutrisi & \multicolumn{3}{c}{ Variasi Fotoperiode } \\
\cline { 2 - 4 } Nitrogen & $12: 12$ & $16: 08$ & $24: 0$ \\
\hline $0 \%$ & $\mathrm{P} 1$ & $\mathrm{P} 2$ & $\mathrm{P} 3$ \\
$25 \%$ & $\mathrm{P} 4$ & $\mathrm{P} 5$ & $\mathrm{P} 6$ \\
$50 \%$ & $\mathrm{P} 7$ & $\mathrm{P} 8$ & $\mathrm{P} 9$ \\
$75 \%$ & $\mathrm{P} 10$ & $\mathrm{P} 11$ & $\mathrm{P} 12$ \\
$100 \%$ & $\mathrm{P} 13$ & $\mathrm{P} 14$ & $\mathrm{P} 15$ \\
\hline \hline
\end{tabular}

Keterangan:

$\mathrm{P} 1=$ Kombinasi Kultur pada nutrisi $\mathrm{N} 0 \%$ dengan fotoperiode 12:12

$\mathrm{P} 2=$ Kombinasi Kultur pada nutrisi $\mathrm{N} 0 \%$ dengan fotoperiode 16:8

$\mathrm{P} 3=$ Kombinasi Kultur pada nutrisi $\mathrm{N}$ 0\% dengan fotoperiode 24:0

$\mathrm{P} 4=$ Kombinasi Kultur pada nutrisi N 25\% dengan fotoperiode 12:12

P5 = Kombinasi Kultur pada nutrisi N 25\% dengan fotoperiode 16:8

P6 = Kombinasi Kultur pada nutrisi N 25\% dengan fotoperiode 24:0 


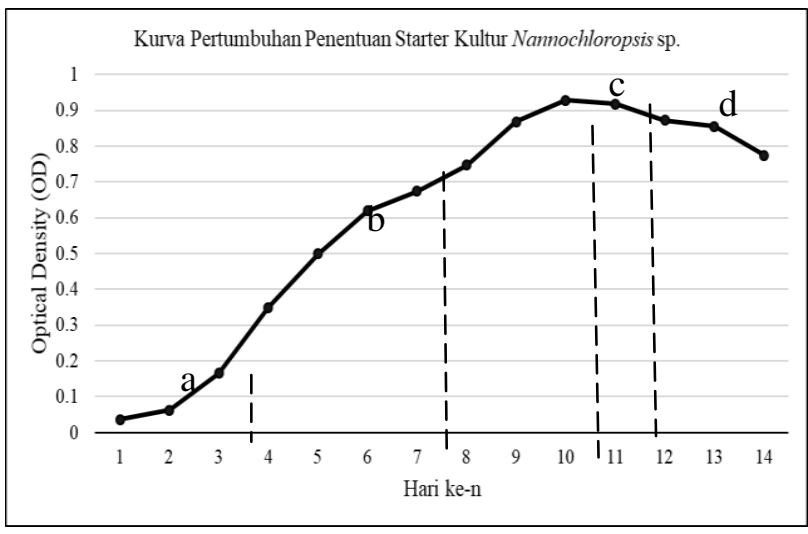

Gambar 1. Kurva Pertumbuhan Nannochloropsis sp. Keterangan: a.Fase Lag, b. Fase Eksponensial, c. Fase Stasioner,d. Fase Death.

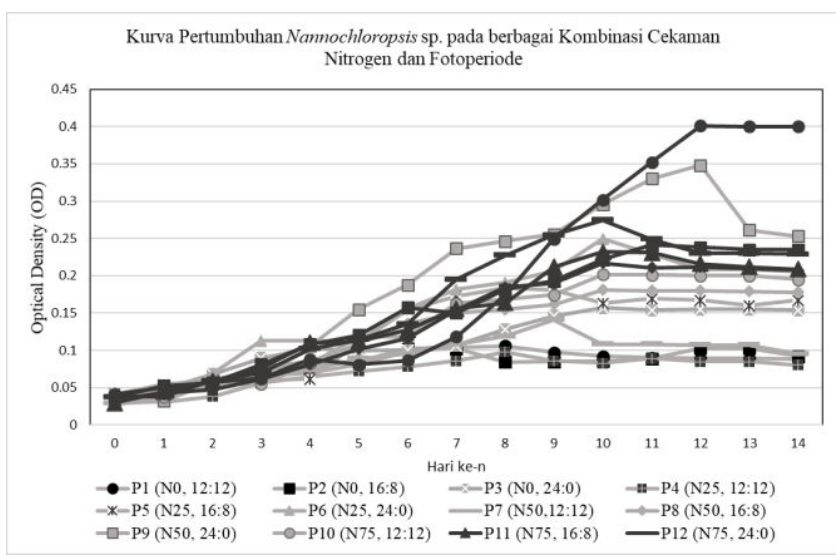

Gambar 2. Panen Kultur pada Berbagai Perlakuan.

P7 = Kombinasi Kultur pada nutrisi $\mathrm{N} 50 \%$ dengan fotoperiode 12:12

P8 = Kombinasi Kultur pada nutrisi N $50 \%$ dengan fotoperiode 16:8

P9 = Kombinasi Kultur pada nutrisi N $50 \%$ dengan fotoperiode 24:0

P10 = Kombinasi Kultur pada nutrisi N 75\% dengan fotoperiode 12:12

P11 = Kombinasi Kultur pada nutrisi $\mathrm{N} 75 \%$ dengan fotoperiode 16:8

$\mathrm{P} 12=$ Kombinasi Kultur pada nutrisi $\mathrm{N} 75 \%$ dengan fotoperiode 24:0

P13 = Kombinasi Kultur pada nutrisi N 100\% dengan fotoperiode 12:12

P14 = Kombinasi Kultur pada nutrisi N 100\% dengan fotoperiode 16:8

P15 = Kombinasi Kultur pada nutrisi N 100\% dengan fotoperiode 24:0

\section{HASIL DAN PEMBAHASAN}

\section{A. Kurva Pertumbuhan Nannochloropsis sp.}

Hasil kurva pertumbuhan dan penentuan waktu starter Nannochloropsis sp. disajikan pada Gambar 1.

Berdasarkan kurva pertumbuhan pada gambar 4.1 aktivitas pertumbuhan Nannochloropsis sp. yang diukur dengan spektrofotometer UV-Vis berupa nilai OD mengalami peningkatan hingga hari ke-10 kultivasi. Hal ini sesuai dengan pernyataan Rodrigues et al, 2011 bahwa Optical Density (OD) pada spektrofotometer dapat memonitoring jumlah sel secara tidak langsung. Sel

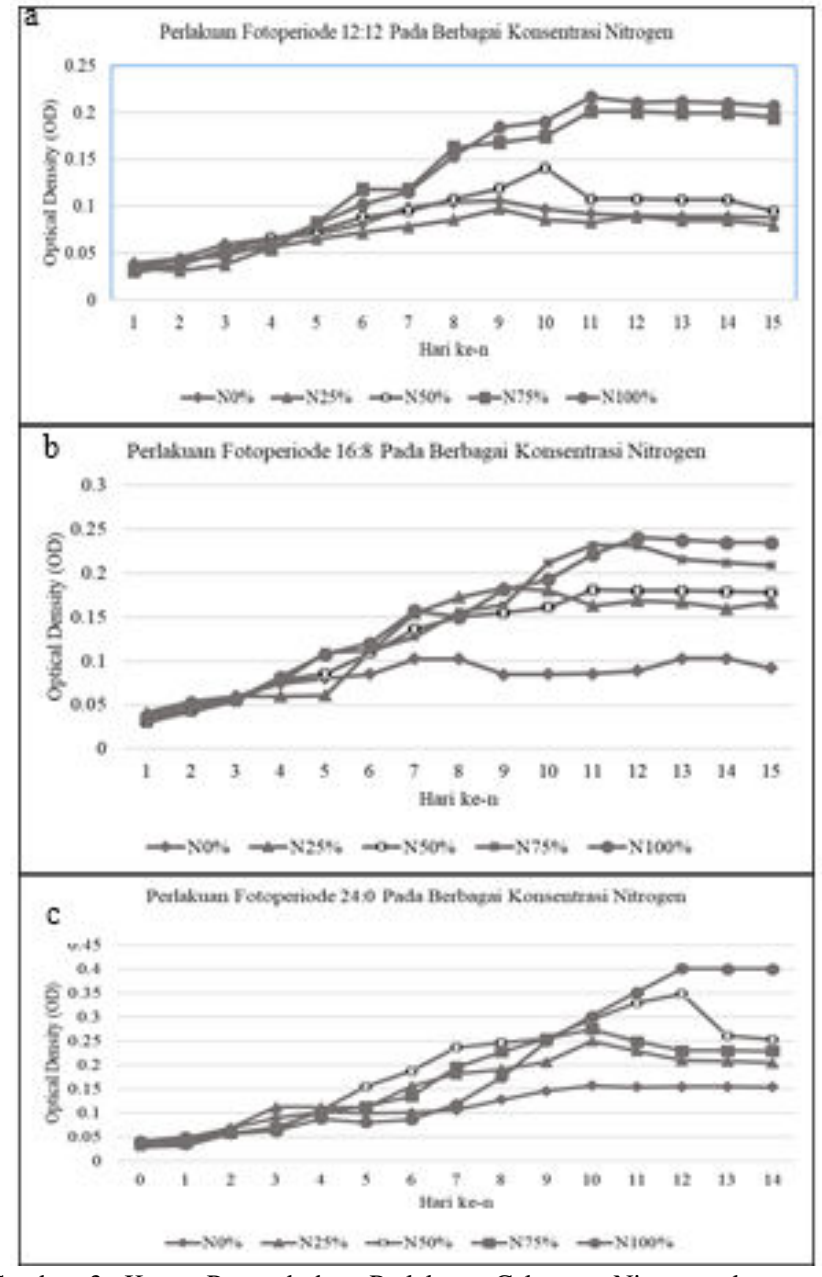

Gambar 3. Kurva Pertumbuhan Perlakuan Cekaman Nitrogen dengan berbagai Konsentrasi dan Fotoperiode

Keterangan: a. Fotoperiode 12:12, b.Fotoperiode 16:8, c.Fotoperiode 24:0

mikroalga yang teramati pada saat kultivasi, mengalami fase lag pada hari ke-1 hingga hari ke-3, kemudian mengalami fase eksponensial pada hari ke-3 hingga hari ke-9, kemudian sel mengalami pertumbuhan yang tetap /stasioner pada hari ke-9 hingga hari ke-10, kemudian sel mengalami penurunan pertumbuhan, memasuki fase kematian pada hari ke-10 hingga hari ke-14. Pada fase stasioner, penambahan kepadatan populasi seimbang dengan laju kematian sehingga pertumbuhan populasi yang terjadi kecil. Jumlah sel cenderung tetap karena telah mencapai titik jenuh. Pada fase death, jumlah sel mengalami penurunan. Penurunan kepadatan sel fitoplankton dapat disebabkan oleh pengurangan nutrisi sehingga mikroalga tidak tumbuh [24].

Berdasarkan kurva pertumbuhan tersebut, massa starter ditentukan pada hari ke-6, yaitu pada setengah masa eksponensial kultur Nannochloropsis sp. tersebut karena sel masih aktif membelah serta dapat melakukan metabolisme secara maksimal sebelum memasuki fase stasioner maupun kematian sel [18][19]. Starter digunakan sebagai bibit untuk pembuatan kultur baru atau untuk produksi massal mikroalga [25].

\section{B. Waktu Panen Kultur pada Berbagai Perlakuan}

Berdasarkan penelitian yag telah dilakukan, diperoleh kurva pertumbuhan kultur Nannochloropsis sp. pada berbagai kombinasi perlakuan yang disajikan pada Gambar 2 . 
Berdasarkan Gambar 2 waktu panen mikroalga Nannochloropsis sp. dengan berbagai kombinasi perlakuan cekaman nitrogen dan fotoperiode memiliki waktu panen yang berbeda. Waktu panen ditentukan berdasarkan fase akhir eksponensial kultur [20] karena pada fase akhir eksponensial mikroalga berada dalam kondisi yang paling optimal, sehingga kandungan nutrisi dalam selnya sangat tinggi. Waktu panen kultur hari ke-6 yaitu pada perlakuan P1 (N0, 12:12), P2 (P0, 16:8). Waktu panen kultur hari ke-8 yaitu pada perlakuan P4 (N25, 12:12), P5 (N25, 16:8). Waktu panen kultur hari ke-9 yaitu pada perlakuan P7 (N50, 12:12), P13 (N100, 12:12). Waktu panen kultur hari ke-10 yaitu pada perlakuan P3 (N0, 24:0), P6 (N25, 24:0), P8 (N50, 16:8), P10 (N75, 12:12), P11 (N75, 16:8), P12 (N75, 24:0). Waktu panen kultur hari ke-11 yaitu pada perlakuan P14 (N100, 16:8). Waktu panen kultur hari ke-12 yaitu pada perlakuan P9 (N50, 24:0), P15 (N100, 24:0).

Berdasarkan jumlah selnya, mikroalga pada perlakuan pemberian nitrogen $100 \%$ memiliki nilai OD (pertumbuhan) yang paling tinggi dibandingkan dengan kultur dengan nitrogen dalam pupuk $75 \%, 50 \%, 25 \%$ dan $0 \%$. Hal ini berkaitan dengan ketersediaan nutrisi untuk tumbuh serta ketersediaan cahaya untuk fotosintesis dan metabolisme sel lainnya. Pada nitrogen yang terpenuhi, sel mikroalga memiliki laju reproduksi yang tinggi sehingga sel yang terbentuk lebih [21] yang ditunjukkan dengan nilai OD pada spektrofotometer yang lebih tinggi.

Gambar 3 adalah kurva pertumbuhan Nannochloropsis sp. pada berbagai konsentrasi nitrogen dan fotoperiode :

Berdasarkan hasil pengamatan tersebut, pemberian nitrogen mempengaruhi pertumbuhan Nannochloropsis sp. dimana tanpa pemberian nitrogen dengan fotoperiode gelap yang lebih panjang, kultur Nannochloropsis sp. memiliki waktu panen yang singkat. Hal ini sesuai dengan literatur yang mengatakan bahwa, kekurangan nitrogen pada alga dapat mempersingkat fase eksponensial alga tersebut [26] sedangkan pemberian nitrogen yang sesuai dan fotoperiode dengan siklus terang yang panjang, kultur Nannochloropsis sp. memiliki waktu panen yang lebih lama serta jumlah sel yang lebih banyak karena nutrisi untuk tumbuh sel terpenuhi, sehingga sel dapat membelah sehingga ukuran serta jumlahnya bertambah.

Fotoperiode yang berkaitan dengan intensitas dan lama pencahayaan berperan dalam proses fotosintesis dimana terjadi pengubahan bahan anorganik menjadi gula sederhana sebagai sumber energi untuk metabolisme sel. Apabila metabolisme sel berjalan maka sel mikroalga dapat tumbuh lebih lama [27]. Hal ini sesuai dengan hasil pengamatan. Selain itu, mikroalga membutuhkan fotoperiodisme yang terdiri dari terang dan gelap yang berbeda-beda. Cahaya terang digunakan pada waktu proses fotokimia untuk menghasilkan ATP, NADPH dan kondisi gelap untuk reaksi biokimia dalam sintesis molekul esensial untuk pertumbuhan [8].

\section{KESIMPULAN}

Berdasarkan penelitian ini dapat disimpulkan bahwa pada nitrogen yang terbatas, fase eksponensial kultur lebih singkat sedangkan pada nitrogen yang tercukupi fase eksponensial kultur lebih panjang. Pada nitrogen $100 \%$ pada semua fotoperiode menghasilkan nilai OD yang tertinggi. Waktu panen tersebut dapat dijadikan informasi untuk produksi biodiesel dengan melakukan uji lanjutan pada kandungan lipid pada setiap perlakuan dengan waktu panen yang telah didapatkan.

Tabel 3.

Perlakuan Kultur

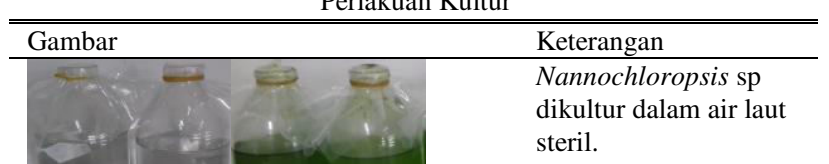

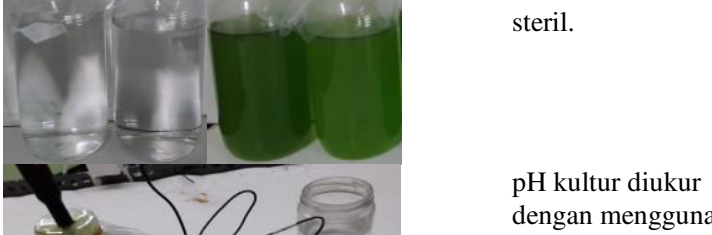
$\mathrm{pH}$ meter.

Salinitas diukur pada 900-1000 lux (terang) dan 0-10 lux (gelap)

Kultur diberikan pupuk dengan nitrogen $0 \%, 25 \%, 50 \%, 75 \%$ dan $100 \%$ pada FP 12:12, 16:8 dan 24:0

Kultur diaerasi dan diukur OD setiap 24 jam dengan spektrofotometer UV Vis $680 \mathrm{~nm}$.

Nilai OD dibuat menjadi kurva pertumbuhan dari fase lag hingga death.

Hasil panen kultur pada fotoperiode 12:12

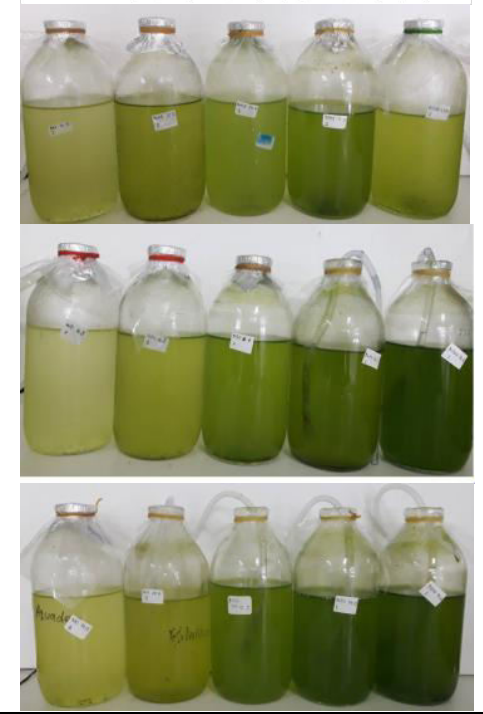

Hasil panen

fotoperiode $16: 8$

Hasil panen kultur dengan berbagai konsentrasi Nitrogen pada fotoperiode $24: 0$ 
Tabel 4.

Nilai OD Penentuan Masa Kultur

\begin{tabular}{|c|c|c|c|c|c|c|c|c|}
\hline \multirow[t]{2}{*}{ No } & \multirow[t]{2}{*}{ Hari } & \multicolumn{3}{|c|}{ OD } & \multicolumn{3}{|c|}{$\mathrm{pH}$} & \multirow{2}{*}{$\begin{array}{c}\text { Suh } \\
\mathrm{u} \\
\left({ }^{\circ} \mathrm{C}\right)\end{array}$} \\
\hline & & I & II & Rerata & B & I & II & \\
\hline 1 & $\begin{array}{c}2 / 20 / 1 \\
8\end{array}$ & 0.037 & $\begin{array}{r}0.035 \\
5\end{array}$ & $\begin{array}{r}0.0362 \\
5\end{array}$ & 7 & 7 & 7 & 24.5 \\
\hline 2 & $\begin{array}{c}2 / 21 / 1 \\
8\end{array}$ & 0.064 & 0.061 & 0.0625 & 7 & 8 & 8 & 24.5 \\
\hline 3 & $\begin{array}{c}2 / 22 / 1 \\
8\end{array}$ & 0.184 & 0.148 & 0.166 & 7 & 8 & 8 & 24.5 \\
\hline 4 & $\begin{array}{c}2 / 23 / 1 \\
8\end{array}$ & 0.331 & 0.368 & 0.3495 & 7 & 8 & 8 & 24.5 \\
\hline 5 & $\begin{array}{c}2 / 24 / 1 \\
8\end{array}$ & 0.469 & 0.531 & 0.5 & 7 & 8 & 8 & 24.5 \\
\hline 6 & $\begin{array}{c}2 / 25 / 1 \\
8\end{array}$ & $\begin{array}{r}0.609 \\
5\end{array}$ & 0.63 & $\begin{array}{r}0.6197 \\
5\end{array}$ & 7 & 8 & 8 & 24.5 \\
\hline 7 & $\begin{array}{c}2 / 26 / 1 \\
8\end{array}$ & $\begin{array}{r}0.633 \\
5\end{array}$ & $\begin{array}{r}0.714 \\
5\end{array}$ & 0.674 & 8 & 8 & 8 & 24.5 \\
\hline 8 & $\begin{array}{c}2 / 27 / 1 \\
8\end{array}$ & $\begin{array}{r}0.696 \\
5\end{array}$ & 0.798 & $\begin{array}{r}0.7472 \\
5\end{array}$ & 8 & 8 & 8 & 24.5 \\
\hline 19 & $\begin{array}{c}2 / 28 / 1 \\
8\end{array}$ & $\begin{array}{r}0.821 \\
5\end{array}$ & 0.914 & $\begin{array}{r}0.8677 \\
5\end{array}$ & 8 & 9 & 9 & 24.5 \\
\hline 10 & $3 / 1 / 18$ & 0.868 & 0.989 & 0.9285 & 8 & 9 & 9 & 24.5 \\
\hline 11 & $3 / 2 / 18$ & 0.824 & 1.011 & 0.9175 & 8 & 9 & 9 & 24.5 \\
\hline 12 & $3 / 3 / 18$ & $\begin{array}{r}0.717 \\
5\end{array}$ & 1.027 & $\begin{array}{r}0.8722 \\
5\end{array}$ & 9 & 9 & 9 & 24.5 \\
\hline 13 & $3 / 4 / 18$ & 0.673 & $\begin{array}{r}1.038 \\
5\end{array}$ & $\begin{array}{r}0.8557 \\
5\end{array}$ & 9 & 9 & 9 & 23 \\
\hline 14 & $3 / 5 / 18$ & 0.523 & $\begin{array}{r}1.025 \\
5 \\
\end{array}$ & $\begin{array}{r}0.7742 \\
5 \\
\end{array}$ & $\begin{array}{l}1 \\
0\end{array}$ & 9 & 9 & 24.7 \\
\hline
\end{tabular}

Tabel 5.

Nilai OD Kultur Fotoperiode 12:12

\begin{tabular}{cccccc}
\hline \hline Hari & N0\% & N25\% & N50\% & N75\% & N100\% \\
\hline 0 & 0.039 & 0.034 & 0.0295 & 0.0315 & 0.0335 \\
1 & 0.044 & 0.031 & 0.0375 & 0.0375 & 0.043 \\
2 & 0.06 & 0.038 & 0.053 & 0.0545 & 0.047 \\
3 & 0.066 & 0.056 & 0.066 & 0.0545 & 0.061 \\
4 & 0.07 & 0.065 & 0.0735 & 0.0825 & 0.0815 \\
5 & 0.0815 & 0.072 & 0.0885 & 0.118 & 0.102 \\
6 & 0.099 & 0.078 & 0.095 & 0.118 & 0.1155 \\
7 & 0.104 & 0.086 & 0.108 & 0.163 & 0.154 \\
8 & 0.106 & 0.0975 & 0.119 & 0.1685 & 0.1845
\end{tabular}

\section{DAFTAR PUSTAKA}

[1] S. Setiadji, T. B. Nila, S. Tety, P. Eko, and W. N. Bebeh., "Alternatif Pembuatan Biodiesel Melalui Transesterifikasi Minyak Castor (Ricinus communis) Menggunakan Katalis Campuran Cangkang Telur Ayam dan Kaolin," J. Penelit. dan Pengemb. Ilmu Kim., vol. 3, no. 1, pp. 1-10, 2017.

[2] T. Prakoso, P. Udomsap, A. Tanaka, T. Hirotsu, and S. Goto, "Characteristics of Oxidative Storage Stability of Canola Fatty Acid Methyl Ester Stabilised with Antioxidant," J. Eng. Sci. ITB, vol. 4, pp. 303-318, 2012.

[3] T. Maharsyah, L. Musthofa, and A.N. Wahyunato, "Efektivitas Penambahan Plant Promoting Bacteria (Azospirillum sp) dalam Meningkatkan Pertumbuhan Mikroalga (Chlorella sp) Pada Media Limbah Cair Tahu Setelah Proses Anaerob," $J$. Keteknikan Pertan. Trop. dan Biosist., vol. 1, no. 3, pp. 258264, 2013.

[4] R. Kwangdinata, R. Indah, and M. Zakir, "Produksi Biodiesel dari Lipid Fitoplankton Nannochloropsis sp. Melalui Metode Ultrasonik," J. Mar. Chim. Acta, vol. 14, no. 2, pp. 29-36, 2013.

[5] M. Mata, A. A. Martins, and N.S. Caetano, "Microalgae for Biodiesel Production and Other Applications: A Review, Renew," Sustain. Energy Rev, vol. 14, pp. 217-232, 2010.

[6] R. Alamsyah, H. L. Enny, and N.C. Siregar, "EsterifikasiTransesterifikasi Dan Karakterisasi Mutu Biodiesel Dari Biji Jarak Pagar (Jatropha curcas Linn)," J. Kim. Kemasan, vol. 33, no. 1, pp. 124-130, 2011.

[7] S. Arita, K. Attaso, and S. Rangga, "Pembuatan Biodiesel Dari Minyak Kelapa Sawit dengan katalis $\mathrm{CaO}$ Disinari Dengan Gelombang Mikro," J. Tek. Kim., vol. 19, no. 4, pp. 45-52, 2013.

[8] M. Gammanpila and S. C.P. Rupasinghe, "Light Intensity and Photoperiode Effect On Growth And Lipid Accumulation Of

\begin{tabular}{cccccc}
9 & 0.097 & 0.086 & 0.141 & 0.1745 & 0.1905 \\
10 & 0.092 & 0.083 & 0.108 & 0.2015 & 0.217 \\
11 & 0.09 & 0.089 & 0.108 & 0.201 & 0.211 \\
12 & 0.089 & 0.085 & 0.107 & 0.2 & 0.212 \\
13 & 0.089 & 0.085 & 0.107 & 0.2 & 0.21 \\
14 & 0.088 & 0.08 & 0.095 & 0.195 & 0.207 \\
\hline \hline
\end{tabular}

Tabel 6.

Nilai OD Fotoperiode 16:8

\begin{tabular}{cccccc}
\hline \hline Hari & N0\% & N25\% & N50\% & N75\% & N100\% \\
\hline 0 & 0.036 & 0.041 & 0.0305 & 0.0295 & 0.037 \\
1 & 0.0455 & 0.054 & 0.0425 & 0.044 & 0.0525 \\
2 & 0.06 & 0.06 & 0.0545 & 0.0585 & 0.0565 \\
3 & 0.0745 & 0.06 & 0.078 & 0.076 & 0.0815 \\
4 & 0.0805 & 0.061 & 0.0855 & 0.11 & 0.108 \\
5 & 0.085 & 0.111 & 0.109 & 0.112 & 0.1205 \\
6 & 0.1025 & 0.1545 & 0.136 & 0.1275 & 0.1575 \\
7 & 0.1025 & 0.173 & 0.15 & 0.156 & 0.15 \\
8 & 0.0845 & 0.1835 & 0.155 & 0.1635 & 0.1815 \\
9 & 0.085 & 0.1805 & 0.1615 & 0.212 & 0.193 \\
10 & 0.0855 & 0.163 & 0.181 & 0.232 & 0.2215 \\
11 & 0.089 & 0.169 & 0.18 & 0.231 & 0.241 \\
12 & 0.103 & 0.167 & 0.18 & 0.216 & 0.238 \\
13 & 0.103 & 0.16 & 0.179 & 0.212 & 0.235 \\
14 & 0.092 & 0.167 & 0.178 & 0.209 & 0.235 \\
\hline \hline
\end{tabular}

Tabel 7.

Nilai OD Fotoperiode 24:0

\begin{tabular}{rrrrrr}
\hline \hline Hari & \multicolumn{1}{c}{ N0\% } & \multicolumn{1}{c}{ N25\% } & N50\% & \multicolumn{1}{c}{ N75\% } & \multicolumn{1}{c}{ N100\% } \\
\hline 0 & 0.0325 & 0.0425 & 0.029 & 0.0375 & 0.041 \\
1 & 0.0485 & 0.037 & 0.032 & 0.038 & 0.0505 \\
2 & 0.068 & 0.069 & 0.057 & 0.059 & 0.0575 \\
3 & 0.0895 & 0.1125 & 0.066 & 0.07 & 0.062 \\
4 & 0.1025 & 0.1125 & 0.106 & 0.102 & 0.088 \\
5 & 0.1 & 0.1115 & 0.155 & 0.114 & 0.0805 \\
6 & 0.1005 & 0.156 & 0.1875 & 0.135 & 0.0865 \\
7 & 0.1065 & 0.1815 & 0.2365 & 0.195 & 0.1185 \\
8 & 0.128 & 0.191 & 0.2465 & 0.2275 & 0.1745 \\
9 & 0.146 & 0.206 & 0.2555 & 0.2545 & 0.2495 \\
10 & 0.157 & 0.2495 & 0.2955 & 0.2745 & 0.302 \\
11 & 0.154 & 0.229 & 0.33 & 0.249 & 0.352 \\
12 & 0.155 & 0.209 & 0.348 & 0.23 & 0.401 \\
13 & 0.155 & 0.208 & 0.261 & 0.23 & 0.4 \\
14 & 0.154 & 0.205 & 0.253 & 0.229 & 0.4 \\
\hline \hline
\end{tabular}

Microalgae Chlorella Vulgaris And Nannochloropsis sp. For Biodiesel Production," in Proceedings of 12th ISERD International Conference, 2015, pp. 51-55.

[9] H. Schuhman, D. K. Y. Lim, and P.M. Scenk, "Perspektive on Metabolic Engineering for Increased Lipid Contents In Microalage," J. Biofuels, vol. 3, pp. 71-86, 2011.

[10] Q. Hu, S. Milton, J. Maria, P. Matthew, S. Michael, and A. Darzins, "Microalgal Tryacylglycerols as Feedstock for Biofuel Production: Perpectives and and Advances," Plant J., vol. 54, pp. 621-639, 20008.

[11] A. Nur, "Potensi Mikroalga sebagai Sumber Pangan Fungsional di Indonesia," J. Eksergi, vol. 11, no. 2, pp. 1-6, 2014.

[12] H. Widianingsih, Retno, E. Hadi, and M. Jane, "Fatty Acid Composition of Marine Microalgae in Indonesia," J. Trop. Biol. Conserv., vol. 10, pp. 75-82, 2013.

[13] K. Nisak, B. S. Raharja, and E.D. Masithah, "Studi Perbandingan Kemampuan Nannochloropsis sp. Dan Chlorella sp. Sebagai Agen Bioremidiasi Terhadap Logam Berat Timbal (Pb)," J. Ilm. Perikan. dan Kelaut., vol. 5, no. 2, pp. 175-180, 2013.

[14] E. Fogg, Algal Cultured and Phytoplankton Ecology. Wisconsin: The University of Wisconsin Press, 1975.

[15] H. Endrawati and I. Riniatsih, "Kadar Total Lipid Mikroalga Nannochloropsis oculate yang Dikultur Dengan Suhu yang Berbeda," Bul. Oseanografi Mar. Januari, vol. 1, pp. 25-33, 2013.

[16] Yarti, M. Muhaemin, and S. Hudaidah, "Pengaruh Salinitas Dan Nitrogen Terhadap Kandungan Protein Total Nannochloropsis sp.," J. Rekayasa Dan Teknol. Budid. Perair., vol. 2, no. 2, pp. 273-278, 2014.

[17] S. Arifah, B. S. Rahardja, and E.D. Masithah, "Studi Kemampuan Nannochloropsis sp. Dan Chlorella sp. Sebagai 
Agen Bioremidiasi Logam Berat Merkuri (Hg) Dan Pengaruhnya Terhadap Pertumbuhan Plankton," J. Mar. Coast. Sci., vol. 6, no. 3, pp. 137-147, 2017.

[18] W. S. Agustin, M. Afriastini, and M. Yoana, "Potential of Fatty Acid from Microalgae Nannochloropsis sp as Antioxidant and Antibacterial," Institut Sains Teknologi Nasional, 2012.

[19] Widayat and Hadiyanto, "Pemanfaatan Limbah Cair Industri Tahu Untuk Produksi Biomassa Mikroalga Nannochloropsis sp Sebagai Bahan Baku Biodiesel," J. Reakt., vol. 15, no. 4, pp. 253-260, 2015.

[20] V. T. Duong, Y. Li, E. Nowak, and M. Scienk, "Microalagae Isolation and Selection for Prospective Biodisel Production," Energies, vol. 5, pp. 1835-1849, 2012.

[21] L. Panggabean, Sutomo, N. Radini, and Afdal, "Mikroalga Laut Sebagai Produsen Biodiesel," 2010.

[22] E. Safitri, R. Diantari, and M. Muhaemin, "Kandungan Lemak Total Nannochloropsis sp Pada Fotoperiode Yang Berbeda," J. Rekayasa dan Teknol. Budid. Perair., vol. 1, no. 2, pp. 127-134, 2013.
[23] H. Suryanto, Sukarni, and Yanuhar, "Studi Eksplorasi Potensi Mikroalga Laut Sebagai Sumber Energi Terbarukan," in Seminar Nasional Teknik Mesin IV, 2009.

[24] Ru'yatin, S. R. Immy, and L. Ali, "Pertumbuhan Tetraselmi dan Nannochloropsis pada Skala Laboratorium," in Pros Sem Nas Masy Biodiv Indon, 2015, pp. 296-299.

[25] P. Perumal, B. B. Prasath, P. Santhanam, S. Ananth, A. S. Devi, and S.D. Kumar, "Isolation and Culture of Microalgae: Workshop on Advances in Aquaculture Technology," Tamil Nadu, 2012.

[26] M. Muhaemin, F. Practica, D. S. Rosi, and A. Tri, "Starvasi Nitrogen dan Pengaruhnya Terhadap Biomassa dan Protein Total Nannochloropsis sp," J. Maspari, vol. 6, no. 2, pp. 98-103, 2014.

[27] A. Alqadi, S. M. Taib, M. F. Din, and H. Kamyab, "Effect Of Photoperiod On The Growth of Chlamydomonas Incerta And Pollutant Removal," Malaysian J. Civ. Eng., vol. 29, no. 1, pp. 69-78, 2017. 